\title{
CONTENTS BY TRADITION
}

One of the purposes of this volume is to demonstrate that the "three religions" of China, Confucianism, Daoism, and Buddhism (with a fourth, popular religion, sometimes added), are not discrete, mutually exclusive traditions, but instead overlap and interact with each other through a variety of confluences and conflicts. Another purpose of the volume is to suggest that the religions of China are not only the products of Han culture; non-Han or "minority" cultures have also influenced and been influenced by the religions of central China. The general table of contents has been organized thematically in order to suggest the continuities and shared concerns that are evident, through the juxtaposition of Confucian, Daoist, Buddhist, "popular," and minority texts. The works in the volume are listed below, somewhat tentatively, under such categories. As in the general table of contents, a work listed in one category could easily be placed under another. For example, "The Scripture on Perfect Wisdom for Humane Kings Who Wish to Protect Their States," listed here as a Buddhist work, could also be considered a work on state religion, while "Daoist Ritual in Contemporary Southeast China," listed here under popular religion, could also be listed under Daoism.

\section{Buddhism}

The Scripture in Forty-two Sections

The Scripture on the Production of Buddha Images

The Scripture on Perfect Wisdom for Humane Kings Who Wish to Protect Their States

The Earliest Tales of the Bodhisattva Guanshiyin

A Sutra Promoting the White-robed Guanyin as Giver of Sons 97

$\begin{array}{ll}\text { Biography of a Buddhist Layman } & 397\end{array}$

Saving the Burning-Mouth Hungry Ghost 278

Visions of Mañjuśri on Mount Wutai 203

$\begin{array}{ll}\text { The Buddhism of the Cultured Elite } & 381\end{array}$

Buddhist Ritual and the State $\quad 390$

\section{Daoism}

The Inner Cultivation Tradition of Early Daoism

Laozi: Ancient Philosopher, Master of Immortality, and God 52

Declarations of the Perfected 166

Seduction Songs of One of the Perfected 180 
Body Gods and Inner Vision: The Scripture of the Yellow Court 149

The Purification Ritual of the Luminous Perfected 268

Abridged Codes of Master Lu for the Daoist Community 347

$\begin{array}{lr}\text { Answering a Summons } & 188\end{array}$

An Early Poem of Mystical Excursion $\quad 156$

Record of Occultists $\quad 446$

Popular Religion

$\begin{array}{ll}\text { Spellbinding } & 241\end{array}$

The Law of the Spirits $\quad 284$

Zhu Xi on Spirit Beings 106

Shrines to Local Former Worthies $\quad 293$

The Lives and Teachings of the Divine Lord of Zitong 64

Supernatural Retribution and Human Destiny 423

Stories from an Illustrated Explanation of the Tract of the Most Exalted on $\begin{array}{ll}\text { Action and Response } & 437\end{array}$

Daoist Ritual in Contemporary Southeast China 306

$\begin{array}{ll}\text { Teachings of a Spirit Medium } & 229\end{array}$

\section{Minority Religions}

The Book of Good Deeds: A Scripture of the Ne People 405

Ny Dan the Manchu Shamaness 223

Calling on Souls and Dealing with Spirits: Three Lahu Ritual Texts 327

A Funeral Chant of the Yi Nationality 337

\section{State Religion}

Deities and Ancestors in Early Oracle Inscriptions 41

Record of the Feng and Shan Sacrifices $\quad 251$

City Gods and Their Magistrates $\quad 72$

Imperial Guest Ritual $\quad 471$ 